\title{
Penggunaan Jasa Freight Forwarder Internasional Untuk Ekspor Benih Lobster Dari Perspektif Hukum Persaingan Usaha
}

\author{
Yetti, \\ Universitas Lancang Kuning, Indonesia, yetti@Unilak.ac.id \\ Indra Afrita \\ Universitas Lancang Kuning, Indonesia, indra_afrita@yahoo.com \\ Deddy Felandry \\ Universitas Lancang Kuning, Indonesia, dfelandry@gmail.com
}

\begin{abstract}
The problem is how to use international freight forwarder services to export lobster seeds in a legal perspective of business competition, what are the legal consequences and use of international freight forwarder services.The research method is normative juridical, which analyzes anti-monopoly laws by conspiring and monopolizing the delivery of lobster seeds, with the data sources being Primary Legal Materials, Secondary Legal Materials and Tertiary Legal Materials. Data collection techniques are literature study, and data analysis with descriptive analysis. The result of the research is that PT ACK, as the freght forwarder, has made allegations against Article 17 regarding monopoly and Article 24 of conspiracy with two other companies, namely KKP, and the Chairperson of the Indonesian Lobster Entrepreneurs Association. The legal consequence of this action resulted in the obstruction of PT ACK's competing business actors from offering export cargo shipping services for lobster seeds abroad, the alleged actions carried out by the three parties could be subject to fines for the perpetrators of this monopoly and conspiracy based on Law No. 11 of 2020 concerning Job Creation, namely a minimum of IDR 1 billion.
\end{abstract}

Keywords: freght forwarder, monopoly, conspiracy

\begin{abstract}
Abstrak
Permasalahan adalah bagaimana Penggunaan Jasa Internasional Freight Forwarder untuk Ekspor Benih Lobster Dalam Perpektif Hukuim Persaingan Usaha bagaimana Akibat Hukum dan Penggunaan Jasa Internaional Freight Forwarder ini. Metode penelitian bersifat yuridis normatif, yang menganalisis dugaan pelanggaran undang-undang anti monopoli dengan cara bersekongkol dan memonopoli pengiriman benih lobster, dengan sumber datanya Bahan Hukum Primer, Bahan Hukum Sekunder dan Bahan Hukum Tertier. Teknik Pengumpulkan Data adalah Studi Kepustakaan, dan analisis data dengan diskriptif analisis. Hasil penelitian adalah bahwa PT ACK, selaku freght forwarder telah melakukan dugaan pelanggaran terhadap Pasal 17 tentang monopoli dan Pasal 24 persekongkolan dengan dua perusahan lainnya yakni KKP, dan Ketua Asosiasi Pengusaha Lobster Indonesia. Akibat hukumnya dengan adanya tindakan tersebut mengakibatkan terhalangnya para pelaku usaha pesaing PT ACK untuk menawarkan jasa kargo angkutan ekspor benih lobster ke luar negeri, tindakan dugaan pelanggaran yang dilakukan tiga pihak tersebut dapat dikenakan denda bagi pelaku monopoli dan persekongkolan ini berdasarkan Undang-Undang No. 11 tahun 2020 tentang Cipta Kerja yakni minimal Rp1 miliar.
\end{abstract}

Kata Kunci : freght forwarder, monopoli, persekongkolan 


\section{A. Pendahuluan}

Salah satu jasa pengiriman barang secara Internasional adalah Internasiona freight forwarder. Internasional freight forwarder adalah sebuah perusahaan yang bergerak dalam bidang keagenan yang mengurusi pengiriman dan penerimaan barang Export dan Import. Freight Forwarder ini bisa dikatakan sebagai agent Shipping Agent / Carrier ${ }^{1}$

Berdasarkan freight forwarder ini adalah usaaha yang .ditujukan untuk mewakili kepentingan pemilik barang untuk mengurus semua kegiatan yang diperlukan bagi terlaksananya pengiriman dan penerimaan barang melalui transportasi darat, laut atau udara dan dapat mencakup kegiatan penerimaan, penyimpanan, sortasi, pengepakan, penandaan, pengukuran, penimbangan, pengurusan penyelesaian dokumen, penerbitan dokumen angkutan, perhitungan biaya angkutan, klaim asuransi atas pengiriman barang serta penyelesaian tagihan dan

\footnotetext{
${ }^{1}$ https://www.akademiasuransi.org/2015/05/apa-itufreight-forwarder.html
}

biaya lainnya berkenaan dengan pengiriman barang-barang tersebut sampai dengan diterimanya barang oleh yang berhak menerimanya ${ }^{2}$

Pemakaian jasa Internasional freight forwarder diantaranya adalah pelaksanaan ekspor lobster yang biasa disebut benur. Penangkapan benih lobster atau benur untuk kemudian dijual ke luar negeri berdampak buruk bagi lingkungan, tidak meningkatkan kesejahteraan nelayan, dan berpotensi menimbulkan praktek kecurangan yakni dugaan pelanggaran terhadap Pasal 17 dan Pasal 24 UU No. 5 Tahun 1999 tentang larangan praktek monopoli dan persaingan usaha tidak sehat.

Hukum mempunyai peranan penting dalam pembangunan ekonomi untuk mewujudkan kesejahteraan sosial ${ }^{3}$. Adakalanya hukum terabaikan oleh dunia usaha.

Dunia usaha merupakan suatu dunia yang boleh dikatakan tidak dapat berdiri

\footnotetext{
${ }^{2}$ Kepmemhub N0. 10 Tahun 1988

${ }^{3}$ Susanti Adi Nugroho, Hukum Persaingan Usaha Di Indonesia Dalam Teori Praktik Serta Penerapan Hukumnya, Edisi Pertama, (Jakarta: Kencana, 2012), hlm. 1-2.
} 
sendiri. Banyak aspek dari berbagai macam dunia lainnya turut terlibat langsung maupun tidak langsung dengan dunia usaha ini. Keterkaitan tersebut kadangkala tidak memberikan prioritas atas dunia usaha, yang pada akhirnya membuat dunia usaha harus tunduk dan mengikuti rambu-rambu yang ada dan seringkali bahkan mengutamakan dunia usaha sehingga mengabaikan aturan-aturan yang telah ada ${ }^{4}$

Dugaan pelanggaran tersebut dilatarbelakangi oleh jasa layanan yang dianggap tidak efisien karena eksportasi hanya dilakukan melalui satu pintu keluar, yakni Bandara Soekarno-Hatta, Tangerang. Padahal, benih lobster didatangkan dari sejumlah daerah, seperti Sumatra Utara dan NTB.

Selain itu, eksportir juga harus menanggung risiko membawa benih lobster yang tergolong sebagai benda hidup, sehingga kedekatan asal benih dan pintu bandara sepatutnya dipertimbangkan. Kemudian juga dalam menetapkan harga

\footnotetext{
4 Hikmahanto Juana, , Sekilas tentang Hukum Persaingan dan UU No. 5 Tahun 1999, Jurnal Magister Hukum I Tahun 1999, hlm. 32.
}

pengiriman ekspor benih yang terbilang tinggi, yakni Rp 1.800 per benih, atau di atas rata-rata harga normal. Perbuatan ini juga menyebabkan biaya logistik ekspor lebih tinggi. Tarif layanan ekspor yang ditetapkan sebesar Rp 1.800 per ekor, jauh di atas harga pasar yang hanya Rp 200-300 per ekor. Imbasnya, pelaku usaha harus menanggung kenaikan biaya tersebut. Pada akhirnya, persoalan ini menyebabkan daya saing produknya menjadi turun.

Dalam pasar monopoli, penetapan harga tersebut didominasi oleh satu pihak, karena tak ada pesaing. Pelaku usaha yang monopoli sudah pasti akan mencari keuntungan sebesar-besarnya dalam pasar. Mereka tidak memikirkan bagaimana produk atau jasa tersebut bisa efisien dan harga jualnya terjangkau oleh masyarakat konsumen. Mereka hanya mencari keuntungan yang besar.

Hal tersebut menyebabkan kerugian bagi semua pihak yang berada dalam mata rantai barang atau jasa yang dimonopoli tersebut. Terutama konsumen yang harus 
membayar harga barang atau jasa yang lebih tinggi dari semestinya. Pembentukan struktur pasar (market structure) yang bersifat monopolistik atau oligopolistik merupakan perwujudan dari kondisi persaingan usaha yang tidak sehat ${ }^{5}$

Dalam kasus ekspor benih lobster, ternyata perusahaan freight forwarder yang melakukan praktik monopoli tersebut bukan perusahaan kargo sebenarnya. Mereka hanya menjadi perantara atau middle man. Perusahaan freight forwarder tidak mengangkut sendiri benih itu ke negara tujuan ekspor, tapi menggunakan jasa kargo lain. Jika tarif yang mereka tetapkan $\mathrm{Rp} 1.800$ per ekor, meraka hanya membayar Rp 300 per ekor pada penyedia jasa kargo lainnya. Mereka tanpa melakukan apapun, mendapatkan cuan sebesar Rp 1.500 per ekor atau lima kali lipat dari harga layanan kargo sebenarnya.

Kalau dibawakan kepada hukum pasar, apabila harga yang ditawarkan

\footnotetext{
${ }^{5}$ Mustafa Kamal Rokan, Hukum Persaingan Usaha Teori dan Praktiknya di Indonesia (Jakarta: Raja Grafindo Persada, 2012), hlm. 1.
}

kepada pelaku usaha tinggi, maka penerima jasa bisa memilih pelaku usaha lain, yang relatif lebih rendah. Akan tetapi pelaku usaha tidak ada pilihan untuk pemakai jasa pelaku usaha lainnya. ${ }^{6}$

Kegiatan penangkapan benih lobster sebagai mata pencaharian masyarakat memang semakin marak dilakukan, paling tidak sejak tahun 2012, di mana sebelumnya kegiatan penangkapan dilakukan untuk pemenuhan kebutuhan benih lobster bagi pembudidaya lobster ${ }^{7}$ Sampai dengan tahun 2018, tercatat volume ekspor lobster dari tahun ke tahun terus meningkat, meskipun sempat mengalami penurunan di tahun $2015^{8}$, setidaknya menandakan bahwa masyarakat, khususnya para nelayan, sampai saat ini masih menggantungkan kelangsungan

\footnotetext{
6 Muhammad Idris , Ini Temuan KPPU Soal Kejanggalan Monopoli Ekspor Benih Lobster di KKP

https://money.kompas.com/read/2020/12/02/110226 926/ini-temuan-kppu-soal-kejanggalan-monopoliekspor-benih-lobster-di-kkp?page=all

7 Erlania, et.al., "Status Pengelolaan Sumberdaya Benih Lobster untuk Mendukung Perikanan Budidaya: Studi Kasus Perairan Pulau Lombok", (Jurnal Kebijakan Perikanan Indonesia JKPI: Vol. 8 No. 2, November 2016), hlm. 90.

${ }^{8}$ Hanif Gusman, "Wacana Ekspor Benih Lobster: Bagaimana Kondisi Lobster di RI”, Tirto, 2020,
} 
hidup mereka pada keberadaan lobster serta

benih lobster. Menanggapi kondisi

tersebut, Pemerintah menganggap bahwa

dengan menghidupkan kembali kegiatan

penangkapan dan ekspor benih lobster

melalui Permen KP No. 12/2020, maka hal

itu akan membawa keuntungan tidak hanya

bagi nelayan, namun juga pembudidaya,

pelaku usaha dan Negara ${ }^{9}$

Meskipun dinyatakan telah

direncanakan jauh sebelum terjadinya

penyebaran virus COVID-19,

pemberlakuan kebijakan izin ekspor benih

lobster melalui PermenKP No. 12/2020

juga bertujuan pada pemulihan ekonomi

yang terdampak akibat terjadinya pandemi tersebut ${ }^{10}$.

Akan tetapi dalam pengirimannya disimpangi oleh pihak-pihak tertentu,

\footnotetext{
9 Medcom.id, "Edhy Prabowo Ingin Tumbuhkan Etos Pembudidayaan Lobster Nasional", Antara, 2020,

https://www.medcom.id/ekonomi/bisnis/ybJGpDwk -edhy-prabowo-ingin-tumbuhkan-etos-

pembudidayaan-lobster-nasional, diakses tanggal 20 September 2020.

${ }^{10}$ Deni Muliya, "Dituding Kebijakan Ekspor Benih Lobster Sembunyi di Balik Pandemi Covid-19, Ini Kata Edhy Prabowo", KompasTV, 2020, https://www.kompas.tv/article/91829/ditudingkebijakan-ekspor-benih-lobster-sembunyi-di-balikpandemi-covid-19-ini-kata-edhy-prabowo, diakses tanggal 20 September 2020
}

dengan menggunakan jasa Internasional freight forwarder, sehingga operasionalnya diduga melanggar Pasal 17 karena melakukan penguasaan atas produksi dan atau pemasaran barang dan atau jasa melalui Internasional freight forwarder oleh satu PT ACK saja. PT ACK memiliki market power di mana pengenaan tarif jasa pengiriman kargo di atas harga biasa yang lebih murah yang bisa dipilih eksportir, dan eksportir tidak punya kesempatan memilih forwarder lainnya $^{11}$

Pasal 17 berbunyi:

(1) Pelaku usaha dilarang melakukan penguasaan atas produksi dan atau pemasaran barang dan atau jasa yang dapat mengakibatkan terjadinya praktek monopoli dan atau persaingan usaha tidak sehat.

(2) Pelaku usaha patut diduga atau dianggap melakukan penguasaan atas produksi dan atau pemasaran

\footnotetext{
${ }^{11}$ https://money.kompas.com/read/2020/12/08/1746 27126/kppu-layangkan-pasal-monopoli-danpersekongkolan-ke-3-eksportir-benur, KPPU Layangkan Pasal Monopoli dan Persekongkolan ke 3 Eksportir Benur Kompas.com - 08/12/2020, 17:46 WIB
} 
barang dan atau jasa sebagaimana dimaksud dalam ayat (1)apabila: :

a. barang dan atau jasa yang bersangkutan belum ada substansinya; atau

b. mengakibatkan pelaku usaha lain tidak dapat masuk ke dalam persaingan usaha barang dan atau jasa yang sama; atau

c. satu pelaku usaha atau satu kelompok pelaku usaha menguasai lebih dari $50 \%$ (lima puluh persen) pangsa pasar satu jenis barang atau jasa tertentu.

Penunjukan satu perusahaan freight forwarder telah mengakibatkan pelaku usaha lain tidak dapat masuk ke dalam persaingan usaha atas barang atau jasa yang sama dan sangat jelas perusahaan tersebut menguasai $100 \%$ pasar penyedia jasa kargo benih lobster. Tindakan ini merupakan kejahatan yang bisa ditindak menggunakan UU Nomor 5 Tahun 1999. Demikian juga dengan adanya dugaan tindakan persekongkolan dengan pelaku usaha lain atau pihak lain untuk menghambat produksi maupun pemasaran barang/jasa Pelaku usaha dilarang bersekongkol, sehingga barang atau jasa di pasar bersangkutan semakin terbatas baik waktu dan jumlahnya.

Pasal 24 berbunyi: Pelaku usaha dilarang bersekongkol dengan pihak lain untuk menghambat produksi dan atau pemasaran barang dan atau jasa pelaku usaha pesaingnya dengan maksud agar barang dan atau jasa yang ditawarkan atau dipasok di pasar bersangkutan menjadi berkurang baik dari jumlah, kualitas, maupun ketepatan waktu yang dipersyaratkan.

Pada Pasal 17 dugaan pelanggaran dilakukan oleh PT ACK (Aero Citra Kargo), dan pada Pasal 24 dugaan pelanggaran dilakukan oleh PT ACK, Tim Uji Tuntas (due diligence ekspor benur), dan Ketua Asosiasi Pelobi (Asosiasi Perkumpulan Pengusaha Lobster Indonesia.

Karena eksportir legal kalah bersaing 
dengan eksportir ilegal (penyelundup), disebabkan harus menanggung beban biaya dari adanya monopoli kargo ekspor benih lobster dan adanya PNBP yang tarifnya memberatkan. Akibatnya pemerintah bisa kehilangan potensi penerimaan PNBP sekitar Rp150 miliar per tahun. ${ }^{12}$

Dengan Demikian Peneliti Melakukan Penelitian Dengan Judul" Penggunaan Jasa Internaional Freight Forwarder untuk Ekspor Benih Lobster Dalam Perpektif Hukuim Persaingan Usaha

\section{Rumusan Masalah}

Dari latar belakang masalah di atas, dirumuskan permasalahan yang diteliti dan dibahas secara lebih mendalam pada penelitian ini, yaitu sebagai berikut:

1. Bagaimanakah Penggunaan Jasa Internaional Freight Forwarder Untuk Pengiriman benih Lobster Ke Luar Negeri Dalam Perpektif UndangUndang No. 5 Tahun 1999”

2. Bagaimanakah Akibat Hukum

12 https://www.jpnn.com/news/monopoli-kargoekspor-benih-lobster-rugikan-nelayan-danpemerintah?page=2 Monopoli Kargo Ekspor Benih Lobster Rugikan Nelayan dan Pemerintah Rabu,
Penggunaan Jasa Internaional freight

Forwarder Untuk Pengiriman Benih

Lobster Ke Luar Negeri Dalam

Perpektif Undang-Undang No. 5

Tahun

\section{Tujuan Penelitian}

Tujuan dari Peneitian ini adalah sebagai berikut :

a. Untuk Menganalisis Penggunaan Jasa Internaional Freight Forwarder untuk Ekspor

Benih Lobster Dalam Perpektif Hukuim Persaingan Usaha

b. Untuk Menganalisis Akibat Hukum Penggunaan Jasa Internaional Freight Forwarder untuk Ekspor Benih Lobster Dalam Perpektif Hukuim Persaingan Usaha

\section{Metode Penelitian}

Jenis Penelitian

Jenis penelitian ini adalah penelitian hukum normatif adalah suatu penelitian yang membahas tentang asas-asas hukum, sistematika hukum, taraf singkronisasi hukum, sejarah hukum, dan perbandingan hukum, yakni dengan lebih memfokuskan 
terhadap persoalan-persoalan yang muncul dan untuk itu peneliti menitik beratkan pembahasan pada ketentuan perundangundangan dan melihat bagaimana hukum dipraktikkan dalam masyarakat. Sifat penelitian ini adalah Penelitian menganalisis kajian norma yang tidak dipatuhi, putusan hakim pengadilan, yang merupakan penelitian kaidah normatif.

Pendekatan penelitian

Pendekatan penelitian yang dipakai adalah Pendekatan Perundang-undangan (Statute Approach). Pendekatan perundangundangan adalah pendekatan yang dilakukan dengan menelaah semua peraturan perundang-undangan dan regulasi yang bersangkut paut dengan isu hukum yang ditangani ${ }^{13}$. Penelitian ini juga mengunakan Pendekatan Kasus (Case Approach) "Pendekatan Kasus (Case Approach) yaitu pendekatan dengan cara melakukan telaah terhadap kasus-kasus yang berkaitan dengan isu yang dihadapi yang telah menjadi putusan pengadilan yang

\footnotetext{
${ }^{13}$ Peter Mahmud Marzuki,Penelitian Hukum (edisi Revisi), Jakarta: Kencana Prenada Media Group, 2013, h.133
}

telah mempunyai kekuatan yang ${ }^{14}$

Sumber Data

Adapun yang menjadi sumber data penelitian hukum normatif ini, adalah data sekunder, dimana data sekunder dalam penelitian ini adalah sebagai berikut :

1. Bahan hukum primer, yaitu bahan-bahan hukum yang mengikat yang dapat terdiri dari

a. Norma atau kaidah dasar, yakni asas-asas hukum.

b. Peraturan perundangan- undangan, yaitu Undang-Undang No. 5 Tahun 1999 tentang Larangan Praktik Mnopoli Dan Persaingan Usaha Tidak Sehat, Undang-undang No. 11/2020 tentang Cipta Kerja yang merevisi besaran denda di UU No. 5/1999. Permen KP Nomor 12/Permen-KP/2020 Tentang Pengelolaan Lobster (Panulirus spp.), Kepiting (Scylla spp.), dan Rajungan (Portunus spp.), di Wilayah Negara Republik Indonesia. 
c. Bahan hukum yang tidak permasalahan yang diteliti.

dikodifikasi.

2. Bahan hukum sekunder, adalah bahan hukum yang memberikan penjelasan ahan hukum primer, yaitu yang dapat berupa rancangan undang-undang, hasilhasil penelitian, hasil karya ilmiah dari kalangan hukum, dan lainnya.

3. Bahan hukum tertier, adalah bahan hukum yang memberikan petunjuk atau penjelasan terhadap bahan hukum primer dan sekunder, misalnya kamus, ensiklopedi, indeks komulatif, dan lainnya.

Teknik Pengumpulan Data

Dalam pengumpulan data

untuk penelitian hukum normatif digunakan metode kajian kepustakaan atau studi documenter. Dalam hal ini seorang peneliti harus jeli dan tepat untuk menemukan data yang terdapat baik dalam peraturan peraturan maupun dalam literature literature yang memiliki hubungan dengan
Analisis Data

Dalam data penulis mengelompokkan berdasarkan persoalan yang ada, kemudian dilakukan pengolahan data. Selanjutnya data tersebut dianalisis secara kualitatif yang kemudian diungkap dalam bahasas dan kalimat secara deskriptif kualitatif, yakni memberikan penjelasan terhadap permasalahan dan penyelesaian permasalahan yang diajukan secara sistematis dan menyeluruh.

Adapun teknik penyimpulan data hasil penelitian digunakan dengan metode induktif yaitu menarik kesimpulan dari pernyataan yang bersifat khusus kedalam pernyataan yang bersifat umum.

\section{B. Hasil Dan Pembahasan}

1. Penggunaan Jasa Internaional Freight Forwarder untuk Ekspor Benih Lobster dalam Perpektif Hukum Persaingan Usaha.

Pemerintah Indonesia menyepakati
untuk melaksanakan berbagai pembaharuan
structural, salah satunya adalah untuk


mengubah ekonomi Indonesia menjadi suatu ekonomi yang terbuka, kompetitif dan efisien ${ }^{15}$. Salah satu implementasi kesepakatan ini adalah proses integrasi perekonomian . Dengan adanya proses integrasi Perekonomian, maka hubungan antara perdagangan dan persaingan tidak hanya mencakup satu negara saja, akan tetapi dapat melibatkan dua atau lebih negara, dengan demikian jangkauan ekonomi menjadi lebih penting dan kompleks. Kebijakan persaingan perlu juga perlu mempertimbangkan dampak dari transaksi terhadap negara pengekspor maupun negara pengimpor, mengingat dampaknya diluar cakupan kebijakan domestik

$$
\text { Di dalam UU No.5/1999 Pasal 50 }
$$

huruf g menyebutkan bahwa “ Perjanjian Atau Perbuatan dengan tujuan ekspor diperbolehkan oleh undang-undang, dengan syarat tidak mengganggu pasokan kebutuhan dalam negeri”. Pada dasarnya dalam sistem perekonomian yang terbuka akan muncul pola perdagangan yang sedemikian kompleks dimana mungkin saja pelaku usaha lokal tidak hanya bertujuan untuk memenuhi kebutuhan

${ }^{15}$ Thee Kian Wie, Aspek-Aspek Ekonomi Yang Perlu Diperhatikan Dalam Implementasi UndangUndang Nomor 5 Tahun 1999, Jakarta: Jurnal Hukum Bisnis Vol.7, hlm. 64. dalam negeri saja tetapi juga untuk ekspor.

Lebih jauh, perilaku pelaku usaha pada umumnya yang bertujuan untuk memaksimalkan keuntungan akan membentuk pola perdagangan yang tertuju pada keuntungan semata tanpa memperhatikan permintaan lokal. Demikian juga dengan proses pengiriman adakalanya mengandung unsur pencegahan, pembatasan, dan penurunan persaingan. Unsur ini merupakan upaya perusahaan untuk memonopoli dengan cara mengurangi atau meniadakan tekanan persaingan. Perilaku ini pada dasarnya adalah perilaku ekslusif, dimana perusahaan monopoli melakukan strategi untuk mengusir pesaing nyata keluar dari pasar atau mencegah masuknya pesaing potensial masuk ke dalam pasar. Dengan hilangnya tekanan persaingan di pasar, meka perusahaan monopoli dapat mengeksploitasi mitra transaksi untuk meningkatkan keuntungannya.

Peraturan Menteri Kelautan dan Perikanan Republik Indonesia No. 12 Tahun 2020 tentang Pengelolaan Lobster (Panulirus spp.), Kepiting (Scylla spp.), 
dan Rajungan (Portunus spp.) di Wilayah

Negara Republik Indonesia (PermenKP

No. 12/2020) membolehkan ekspor benih

lobster dari wilayah Indonesia yang sebelumnya dilarang ${ }^{16}$ Terkait dengan peraturan menteri kelautan ini PT ACR melakukan kegiatan penggunaan Jasa Internaional Freight Forwarder terhadap pengiriman benih lobster dengan model yang didesain lewat kebijakan dan regulasi birokrasi. Internasional freight forwarder adalah sebuah perusahaan yang bergerak dalam bidang keagenan yang mengurusi pengiriman dan penerimaan barang Export dan Import. Freight Forwarder ini bisa dikatakan sebagai agent Shipping Agent / Carrier ${ }^{17}$.

Ada beberapa indikasi yang dilakukan oleh PT ACK dalam pengiriman anak lobster ini yang mengarah kepada monopoli dan persekongkolan.

${ }^{16}$ Dina, K. B., \& Hasanah, H. (2020). Analisis Permen KP No. 12/2020 Terkait Kebijakan Ekspor Benih Lobster berdasarkan Prinsip Pembangunan Berkelanjutan pada New Normal. Jurnal Hukum Lingkungan Indonesia, 7(1), https://doi.org/10.38011/jhli.v7i1.223

17 (https://www.akademiasuransi.org/2015/05/apaitu-freight-forwarder.html
Beberapa indikasi yang mengarah kepada praktik monopoli dan persekongkolan adalah sebagai betrikut:

1. Adanya indikasi para eksportir harus menggunakan satu perusahaan tertentu.

Untuk mengekspor benih lobster, para eksportir harus menggunakan satu perusahaan tertentu yang ditetapkan KKP sebagai penyedia layanan kargo (freight forwarder). Meski pun kebijakan KKP tersebut tidak secara spesifik menyebutkan penyedia kargo tunggal dalam regulasi. Namun dalam berbagai kondisi oknum KKP yang sifatnya non formal selalu mengarahkan penggunaan perusahaan PT ACK sebagai reight forwarder. Akibatnya bagi eksportir yang tidak menggunakan perusahaan tersebut, Surat Keterangan Waktu Pengeluaran (SKWP) tidak akan diterbitkan oleh Kementerian Kelautan. Sementara SKWP merupakan persyaratan utama bagi eksportir agar bisa mengekspor benih lobster. Degan demikian eksportir tidak punya pilihan lain dalam menggunakan jasa freight forwarder dalam melakukan ekspor, dimana salah satu syarat dikatakan bahwa monopoli tidak adanya barang pengganti atau substitusi. Demikian juga bahwa 
dalam pengertian monopoli dinyatakan monopoli didefinisikan sebagai pemusatan kekuatan ekonomi oleh satu atau lebih pelaku usaha yang mengakibatkan dikuasainya produksi dan/atau pemasaran atas barang dan/atau jasa tertentu sehingga menimbulkan persaingan usaha tidak sehat dan dapat merugikan pelaku usaha ${ }^{18}$.

Penunjukan satu perusahaan freight forwarder telah mengakibatkan pelaku usaha lain tidak dapat masuk ke dalam persaingan usaha atas barang atau jasa yang sama dan sangat jelas perusahaan tersebut menguasai $100 \%$ pasar penyedia jasa kargo benih lobster. Ini merupakan kejahatan yang bisa ditindak menggunakan UU Nomor 5 Tahun 1999. Diundangkannya Undang-Undang Nomor 5 Tahun 1999 bermaksud sebagai tool of social control and tool of social engineering. Sebagai "alat control sosial", Undang-Undang Nomor 5 Tahun 1999 berusaha menjaga kepentingan umum dan mencegah praktik monopoli dan/ atau persaingan usaha tidak sehat. Selanjutnya,

${ }^{18}$ Andi Fahmi Lubis, et al, 2009, Hukum Persaingan Usaha Antar Teks dan Konteks, Jakarta: Deutsche Gesellshaft fur Technishe Zusammenarbeit (GTZ) Gmb H, hlm. 15 sebagai "alat rekayasa sosial"19 UndangUndang Nomor 5 Tahun 1999, berusaha untuk meningkatkan efisiensi ekonomi nasional, mewujudkan iklim usaha yang kondusif melalui pengaturan persaingan usaha yang sehat dan berusaha menciptakan efektivitas dan efisiensi dalam kegiatan usaha.

2. Biaya logistik ekspor lebih tinggi. Tarif layanan ekspor yang ditetapkan untuk satu ekor benur sebesar Rp 1.800 (seribu delapan ratus rupiah). Sementara harga normal di pasaran hanya $\mathrm{Rp} 200$ - Rp 300 per ekor. Berarti Pelaku usaha harus menanggung kenaikan dari harga normal sebesar Rp 1.500 - Rp 1.600, per ekor benur. Sementara pelaku usaha tidak punya pilihan alternatif lain untuk melakukan pengiriman. Ini yang disebut salah satu ciri-ciri monopoli tidak ada barang pengganti atau substitusi. pelaku usaha jauh di atas harga pasar yang hanya Rp 200-300 per ekor. Imbasnya, pelaku usaha harus menanggung kenaikan biaya

\footnotetext{
19 Zuhro Puspitasari, Rekonsepsi Pengecualian Monopoli Yang Diselenggarakan Oleh Badan Usaha Milik Negara Dalam Hukum Persaingan Usaha Di Indonesia .Jurnal Panorama Hukum Vol. 2 No. 2 Desember 2017 ISSN : 2527-6654, hlm 228
} 
tersebut. Pada akhirnya, persoalan ini menyebabkan daya saing produknya menjadi turun.

Dalam persaingan usaha merupakan sebuah proses dimana para pelaku usaha seharusnya menjadi perusahaan yang efisien dengan penawaran pilihan-pilihan produk dan jasa dalam harga yang lebih rendah $^{20}$

Ini sudah lumrah terjadi pada pasar monopoli, bahwa penetapan harga tersebut didominasi oleh satu pihak yang kuat, karena tak ada pesaing. Pelaku usaha yang monopoli sudah pasti akan mencari keuntungan sebesar-besarnya dalam pasar. Pelaku usaha tidak memikirkan bagaimana produk atau jasa tersebut bisa efisien dan harga jualnya terjangkau oleh masyarakat konsumen, kecuali keuntungan yang sebesar-besarnya

Hal tersebut menyebabkan kerugian bagi semua pihak yang berada dalam mata rantai barang atau jasa yang dimonopoli

20 Artina Wahyu Dwi Nugrahaeni Tantangan dan Pengaturan Price Discrimination: Studi Komparatif Indonesia dan Malaysia Jurnal Ilmiah Dunia Hukum Volume 3 Nomor 2, April 2019 ISSN Print: 2528-6137 tersebut. Terutama konsumen yang harus membayar harga barang atau jasa yang lebih tinggi dari semestinya.

3. Perusahaan freight forwarder milik PT ACK yang melakukan dugaan praktik monopoli tersebut bukan perusahaan kargo sebenarnya. Melainkan hanya menjadi perantara atau middle man. monopoli merupakan kekuatan besar yang dapat digunakan untuk mengatur harga pasar ${ }^{21}$ Perusahaan freight forwarder mengalihkan pengiriman tersebut ke pihak ke tiga atau memilih kargo lainnya ke negara tujuan ekspor. Dengan demikian Perusahaan freight forwarder tidak mengangkut sendiri benih itu ke negara tujuan ekspor, akan tetapi menggunakan jasa kargo lain. Tarif yang harus dibayar oleh kosumen sebesar Rp 1.800,- per ekor, kepada Perusahaan freight forwarder, maka Perusahaan freight forwarder hanya menyerahkan Rp 300,-tarif yang mereka tetapkan Rp 1.800 per ekor, meraka hanya

\footnotetext{
${ }^{21}$ Badriyah Rifai , Mencermati Isi dan Visi Undangundang Nomor 5 Tahun 1999 tentang Anti Monopoli JURNAL HUKUM. N0.17 VOL 8. JUNI2001: hlm 73-86
} 
membayar Rp 300,- per ekor pada penyedia jasa kargo lainnya. PT ACK tanpa melakukan apapun mendapat keuntungan sebesar $\mathrm{Rp} 1.500,-$ tanpa melakukan tindakan aoapun, kecuali hanya sebagai perantara. Berart Perusahaan freight forwarder mendapat keuntungan $5 \mathrm{X}$ lipat tanpa melakukan tindakan yang berrati. ${ }^{22}$

Tindakan ini jika tidak segera diantisipasi akan sangat merugikan negara Indonesia karena produk perikanan Indonesia terdapat lobster yang bernilai jual tinggi. Teluk Bumbang di Kabupaten Lombok Tengah dan Teluk Ekas di Kabupaten Lombok Timur, Nusa Tenggara Barat (NTB) merupakan penghasil utama lobster di Indonesia dan berkualitas dunia. Dalam setahun, dihasilkan 78,5 ton lobster senilai Rp 55,25 miliar dan nilai ekonomi penjualan benih lobster mencapai $\mathrm{Rp} 16$ miliar per tahun ${ }^{23}$

\footnotetext{
22 (https://analisis.kontan.co.id/news/monopolibelajar-dari-kasus-ekspor-lobster)

${ }^{23}$ Lombok Penghasil Utama Lobster di Indonesia diakses dari https://m.tempo.co/read/news/ pada 17 Mei 2016 pukul 18.50 WIB
}

4. Pengiriman BBL yang dilakukan melalui satu bandara, yakni Bandara Soekarno Hatta Jakarta dapat menciptakan inefisiensi bagi biaya pengiriman dan resiko yang harus ditanggung oleh pelaku usaha. Padahal, pilihan bandar udara yang dapat menjadi akses pengiriman tidak hanya Bandara Soekarno Hatta. Berdasarkan Keputusan Kepala Badan Karantina Ikan Pengendalian Mutu dan Keamanan (BKIPM) Nomor 37 Tahun 2020 tentang Tempat Pengeluaran Khusus Benih Bening Lobster dari Wilayah Negara RI telah menetapkan adanya 6 (enam) bandara yang direkomendasikan untuk pengiriman BBL ke luar negeri, yakni Bandara Soekarno Hatta, Bandara I Gusti Ngurah Rai Denpasar, Bandara Juanda Surabaya, Bandara Internasional Lombok, Bandara Kualanamu Medan dan Bandara Hasanuddin Makassar.

Secara praktek, seharusnya dengan memperhatikan sebaran lokasi pembudi daya lobster, maka biaya yang dikeluarkan eksportir akan lebih murah apabila keenam 
bandara yang direkomendasikan dapat difungsikan sebagai tempat pengeluaran BBL. Dengan biaya pengiriman domestik yang lebih rendah tersebut, maka harga BBL akan lebih bersaing di pasar.

Demikian juga tingkat risiko mortalitas BBL juga akan turun, karena BBL dapat diterima di Negara tujuan dalam kondisi segar dan dapat memberikan keuntungan bagi eksportir.. ${ }^{24}$

\section{Akibat hukum Penggunaan Jasa} Internaional Freight Forwarder untuk Ekspor Benih Lobster dalam Perpektif Hukum Persaingan Usaha.

Pasal 17 UU No. 5 Tahun 1999 Pasal tersebut menyebut bahwa pelaku usaha dilarang melakukan penguasaan atas produksi dan atau pemasaran barang dan atau jasa yang dapat mengakibatkan praktik monopoli atau persaingan secara tidak sehat.

Dugaan pelanggaran pasal 17 ini juga ditujukan kepada PT ACK yang dapat menyebabkan persaingan usaha tidak sehat, sehingga dapat dikenakan anacaman 24

https://www.hukumonline.com/berita/baca/lt5fae 5 bf bc $5 \mathrm{c} 1 \mathrm{~b} / \mathrm{kppu}$-selidiki-dugaan-praktik-monopolidalam-ekspor-benih-bening-lobster/ hukuman pelaku

dugaan monopoli perusahaan freight forwarding atas jasa pengangkutan dan pengiriman benih bening lobster (BBL), dengan ancaman denda minimum Rp 1 miliar, sebagaimana diatur dalam Undang-Undang No 11 Tahun 2020 tentang Cipta Kerja.

Dugaan monopoli dapat dilihat dari ekspor benih lobster hanya dilakukan oleh satu perusahaan yaitu PT ACK. Hal ini menyebabkan market power dan jasa pengiriman kargo harga menjadi tinggi, dan kesempatan untuk memilih (freight forwarding) terhadap pengiriman kargo lainnya menjadi tertutup. Kemudian juga penetapan harga yang di luar kewajaran, maupun hambatan-hambatan dalam pemilihan atau penggunaan jasa freight forwarder lain untuk pengiriman benih lobster ke luar negeri.

Disamping itu juga akan menyebabkan pekaku usaha yang berada pada posisi monopoli akan menenpati posisi dominan. Dengan posisi dominan 
tersebut pelaku usaha tentu akan terus mencari keuntungan tanpa batas, sehingga akan cenderung melakukan tindakan penyalahgunaan posisi dominan ${ }^{25}$. dalam Pasal 1 angka 4 Undang-Undang Nomor 5 Tahun 1999 menyebutkan posisi dominan merupakan suatu keadaan dimana pelaku usaha tidak mempunyai pesaing yang berarti di pasar bersangkutan dalam kaitan dengan pangsa yang dikuasai dengan kemampuan keuangan, kemampuan akses pada pasokan, penjualan, serta kemampuan untuk menyesuaikan pasokan dan permintaan barangatau jasa tertentu ${ }^{26}$

Pelaku usaha yang memiliki posisi dominan memiliki sejumlah kemungkinan yang berpotensi melakukan perilaku anti persaingan,yaitu (1) Menetapkan harga berlebih (Charging excessive price), (2) Melakukan diskriminasi harga (Price discrimination), (3) Menetapkan harga yang mematikan (Predatory pricing), (4) Menolak bertransaksi (Refusal to deal/sell), (5) Melakukan jual ikat (Tied-in selling),

25 Anang Triyono, Penyalahgunaan Posisi Dominan Oleh Pelaku Usaha: Studi Kasus Pada Audit PT. Telekomunikasi Indonesia, Tbk Tesis, Fakultas Ekonomi Program Magister Perencanaan \& Kebijakan Publik Jakarta Januari 2010

${ }^{26}$ Pasal 1 ayat 4 UU No. 5 Tahun 1999
(6) Preemption of facilities, (7) Tacit collusion, dan (8) Menaikkan biaya pesaing $^{27}$

Selain itu juga memiliki maksud (intent) atau tujuan utama pelaku usaha melaksanakan kebijakannya. Sehingga jika unsur tersebut telah terpenuhi maka dengan unsur tersebut dapat dikualifikasikan sebagai Kejahatan Korporasi karena perilaku yang dilakukan oleh pelaku usaha dalam hal ini korporasi sangat merugikan masyarakat. ${ }^{28}$

Pelaku-pelaku usaha yang dominan bahkan berkembang menjadi konglomerasi di berbagai sektor. Ada kalanya persaingan secara tidak sehatpun dapat terjadi diantara pelaku kegiatan ekonomi dan bisnis curang pun banyak mewarnainya. Kecurangan yang terjadi disebabkan karena keserakahan manusia yang tidak pernah terpuaskan. ${ }^{29}$

Dalam Pasal 25 ayat (2) dijelaskan

\footnotetext{
${ }^{27} \mathrm{Ibid}$

${ }^{28}$ Muhammad Fikri Alfarizi, Lucky Endrawati, Hanif Nur Widhiyanti, Penyalahgunaan Posisi Dominan Dalam Perspektif Kejahatan Korporasi Berdasarkan Undang-Undang Nomor 5 Tahun 1999 Tentang Larangan Praktek Monopoli Dan Persaingan Usaha Tidak Sehat Fakultas Hukum Universitas Brawijaya, http://hukum.studentjournal.ub.ac.id/index.php/huk $\frac{\mathrm{um}}{29}$

${ }^{29}$ Dewi Astutty Mochtar, Penyalahgunaan Posisi Dominan Dalam Kepemilikan Saham Silang, Jurnal Cakrawala Hukum, Vol.18, No.2 Desember 2013, hlm. 116-126
} 
mengenai pelaku usaha memiliki posisi dominan apabila:

a. Satu pelaku usaha atau satu kelompok pelaku usaha menguasai 50\%; atau

b. Lebih pangsa pasar satu jenis barang atau jasa tertentu; atau

c. Dua atau tiga pelaku usaha atau kelompok pelaku usaha menguasai $75 \%$ atau lebih pangsa pasar satu jenis barang atau jasa tertentu.

Tindakan yang dilakukan oleh PT ACK tidak hanya menguasai pangsa pasar denagn KKP, dan Ketua Asosiasi Pengusaha Lobster Indonesia, bukan hanya menguasai pasar $75 \%$, akan tetapi $100 \%$, sehingga para eksportir tidak mempunyai piliahn lain untuk melakukan ekpor BBL, yang dalam hal ini adalah pemakaian jasa pengiriman internasional feight forwaarder.

\section{Kesimpulan}

Penggunaan Jasa Internaional Freight Forwarder untuk Ekspor Benih Lobster dalam Perpektif Hukum Persaingan Usaha, diduga melanggar Undang-Undang No. 5 Tahun 1999 terutama pasal 17 yakni melkaukan tindakan monopoli, dimana Pelaku usaha dilarang melakukan penguasaan atas produksi dan atau pemasaran barang dan atau jasa yang dapat mengakibatkan terjadinya praktek monopoli dan atau persaingan usaha tidak sehat., dengan indikasi Adanya indikasi para eksportir harus menggunakan satu perusahaan tertentu, Biaya logistik ekspor lebih tinggi dimana tarif layanan ekspor yang ditetapkan untuk satu ekor benur sebesar Rp 1.800 (seribu delapan ratus rupiah). Sementara harga normal di pasaran hanya $\quad R p 200$ - Rp 300 per ekor, sementara eksportir tidak punya pilihan lain, Perusahaan freight forwarder milik PT ACK yang melakukan dugaan praktik monopoli tersebut bukan perusahaan kargo sebenarnya, melainkan hanya menjadi perantara atau middle man. Pengiriman BBL yang dilakukan melalui satu bandara, yakni Bandara Soekarno Hatta Jakarta seharusnya adanya 6 (enam) bandara yang direkomendasikan untuk pengiriman BBL ke luar negeri, yakni Bandara Soekarno Hatta, Bandara I Gusti Ngurah Rai Denpasar, Bandara Juanda Surabaya, Bandara Internasional Lombok, Bandara 
Kualanamu Medan dan Bandara

Hasanuddin Makassar.

Akibat hukumnya, bahwa PT ACK dapat dikenakan denda mionimal 1 M sebagaimana ketentuan dalam UU No. 11 Tahun 2020, tentang Undang-Undang Cipta Kerja, dan terjadinya penyalahgunaan posisi dominan karena dengan adanya monopoli dapae melakukan penguasaan pasar.

\section{Daftar Pustaka}

Buku

Andi Fahmi Lubis, et al, Hukum Persaingan Usaha Antar Teks dan Konteks, Jakarta, 2009

Susanti Adi Nugroho, Hukum Persaingan Usaha Di Indonesia Dalam Teori Praktik Serta Penerapan Hukumnya, Edisi Pertama,

(Jakarta: Kencana, 2012).

Mustafa Kamal Rokan, Hukum Persaingan Usaha Teori dan Praktiknya di
Indonesia, Jakarta, Raja Grafindo Persada, 2012

Peter Mahmud Marzuki,Penelitian Hukum (edisi Revisi), Jakarta: Kencana Prenada Media Group, 2013

\section{Tugas Akhir}

Anang Triyono, Penyalahgunaan Posisi Dominan Oleh Pelaku Usaha: Studi Kasus Pada Audit PT. Telekomunikasi Indonesia, Tbk Tesis, Fakultas Ekonomi Program Magister Perencanaan \& Kebijakan Publik Jakarta Januari 2010

\section{Jurnal}

Artina Wahyu Dwi Nugrahaeni Tantangan dan Pengaturan Price Discrimination: Studi Komparatif Indonesia dan Malaysia Jurnal Ilmiah Dunia Hukum Volume 3 Nomor 2, April 2019 ISSN

Badriyah Rifai, Mencermati Isi dan Visi Undang-undang Nomor 5 Tahun 1999 tentang Anti Monopoli JURNAL HUKUM. N0.17 VOL 8. JUNI2001: hlm 73-86 
Dewi Astutty Mochtar, Penyalahgunaan Posisi Dominan Dalam Kepemilikan Saham Silang, Jurnal Cakrawala Hukum, Vol.18, No.2 Desember 2013, hlm. 116-126

Dina, K. B., \& Hasanah, H. (2020). Analisis Permen KP No. 12/2020 Terkait Kebijakan Ekspor Benih Lobster berdasarkan Prinsip Pembangunan Berkelanjutan pada New Normal. Jurnal Hukum Lingkungan Indonesia, 7(1), 48-70 https://doi.org/10.38011/jhli.v7i1.2 23

Erlania, et.al., "Status Pengelolaan Sumberdaya Benih Lobster untuk Mendukung Perikanan Budidaya: Studi Kasus Perairan Pulau Lombok", (Jurnal Kebijakan Perikanan Indonesia JKPI: Vol. 8 No. 2, November 2016), hlm. 90.

Hikmahanto Juana, , Sekilas tentang Hukum Persaingan dan UU No. 5 Tahun 1999, Jurnal Magister Hukum I Tahun 1999, hlm. 32.
Muhammad Fikri Alfarizi, Lucky Endrawati, Hanif Nur Widhiyanti, Penyalahgunaan Posisi Dominan Dalam Perspektif Kejahatan Korporasi Berdasarkan UndangUndang Nomor 5 Tahun 1999 Tentang Larangan Praktek Monopoli Dan Persaingan Usaha Tidak Sehat Fakultas Hukum Universitas Brawijaya, http://hukum.studentjournal. ub.ac.id/index.php/hukum

Thee Kian Wie, Aspek-Aspek Ekonomi Yang Perlu Diperhatikan Dalam Implementasi UndangUndang Nomor 5 Tahun 1999, Jakarta: Jurnal Hukum Bisnis Vol.7, hlm. 64.

Zuhro Puspitasari, Rekonsepsi Pengecualian Monopoli Yang Diselenggarakan Oleh Badan Usaha Milik Negara Dalam Hukum Persaingan Usaha Di Indonesia .Jurnal Panorama Hukum Vol. 2 No. 2 Desember 2017 ISSN : 2527-6654, hlm 228

\section{Internet}


https://www.hukumonline.com/berita/baca/

$\underline{\text { tt5fae } 5 \mathrm{bfbc} 5 \mathrm{c} 1 \mathrm{~b} / \mathrm{kppu} \text {-selidiki- }}$

dugaan-praktik-monopoli-dalam-

ekspor-benih-bening-lobster/

Muhammad Idris , Ini Temuan KPPU Soal

Kejanggalan Monopoli Ekspor Benih

Lobster di KKP

https://money.kompas.com/read/2020/12/0

2/110226926/ini-temuan-kppu-soal-

kejanggalan-monopoli-ekspor-benih-

$\underline{\text { lobster-di-kkp?page }=\text { all }}$

Medcom.id, "Edhy Prabowo Ingin

Tumbuhkan Etos Pembudidayaan

Lobster Nasional", Antara, 2020, https://www.medcom.id/ekonomi/bis nis/ybJGpDwk-edhy-prabowo-ingin-

tumbuhkan-etos-pembudidayaan-

lobster-nasional, diakses tanggal 20

September 2020.

Deni Muliya, "Dituding Kebijakan Ekspor Benih Lobster Sembunyi di Balik Pandemi Covid-19, Ini Kata Edhy Prabowo”, KompasTV, 2020, https://www.kompas.tv/article/91829 /dituding-kebijakan-ekspor-benih- lobster-sembunyi-di-balik-pandemi-

covid-19-ini-kata-edhy-prabowo,

diakses tanggal 20 September 2020

Hanif Gusman, "Wacana Ekspor

Benih Lobster: Bagaimana Kondisi

Lobster di RI", Tirto, 2020,

https://money.kompas.com/read/2020/12/0

8/174627126/kppu-layangkan-pasal-

monopoli-dan-persekongkolan-ke-3-

eksportir-benur, KPPU Layangkan

Pasal Monopoli dan Persekongkolan

ke 3 Eksportir Benur Kompas.com -

08/12/2020, 17:46 WIB

https://www.jpnn.com/news/monopoli-

kargo-ekspor-benih-lobster-rugikan-

nelayan-dan-pemerintah?page $=2$

Monopoli Kargo Ekspor Benih

Lobster Rugikan Nelayan dan

Pemerintah Rabu,

https://www.akademiasuransi.org/2015/05/

apa-itu-freight-forwarder. html

Deutsche Gesellshaft fur Technishe

Zusammenarbeit (GTZ), hlm. 15

(https://analisis.kontan.co.id/news/m

onopoli-belajar-dari-kasus-ekspor- 
lobster) Lombok Penghasil Utama

Lobster di Indonesia diakses dari https://m.tempo.co/read/news/ pada

17 Mei 2016 pukul 18.50 WIB

\section{Undang-Undang}

Kepmemhub N0. 10 Tahun 1988

Undang-Undang No. 5 Tahun 1999

tentang Larangan Praktik Monopoli

dan Persaingan Usaha Tidak Sehat 